\title{
TFA Product Delivery Expectations Idaho Low Activity Waste Immobilization
}

by

\author{
E. W. Holtzscheiter
}

Westinghouse Savannah River Company

Savannah River Site

Aiken, South Carolina 29808

J. R. Harbour

This paper was prepared in connection with work done under the above contract number with the U.S. Department of Energy. By acceptance of this paper, the publisher and/or recipient acknowledges the U.S.

Government's right to retain a nonexclusive, royalty-free license in and to any copyright covering this paper, along with the right to reproduce and to authorize others to reproduce all or part of the copyrighted paper. 


\section{DISCLAIMER}

This report was prepared as an account of work sponsored by an agency of the United States Government. Neither the United States Government nor any agency thereof, nor any of their employees, makes any warranty, express or implied, or assumes any legal liability or responsibility for the accuracy, completeness, or usefulness of any information, apparatus, product, or process disclosed, or represents that its use would not infringe privately owned rights. Reference herein to any specific commercial product, process, or service by trade name, trademark, manufacturer, or otherwise does not necessarily constitute or imply its endorsement, recommendation, or favoring by the United States Government or any agency thereof. The views and opinions of authors expressed herein do not necessarily state or reflect those of the United States Government or any agency thereof.

This report has been reproduced directly from the best available copy.

Available to DOE and DOE contractors from the Office of Scientific and Technical Information, P.O. Box 62, Oak Ridge, TN 37831; prices available from (615) 576-8401.

Available to the public from the National Technical Information Service, U.S. Department of Commerce, 5285 Port Royal Road, Springfield, VA 22161. 


\section{DISCLAIMER}

Portions of this document may be illegible in electronic image products. Images are produced from the best available original document. 
WSRC-RP-00846

\section{TFA Product Delivery Expectation Idaho Low Activity Waste Immobilization}

By

E.W. Holtzscheiter

Westinghouse Savannah River Company

Savannah River Site

Aiken, South Carolina 29808

J.R. Harbour

DOE Contract No. DE-AC09-96SR18500

This paper was prepared in connection with work done under the above contract number with the U.S. Department of Energy. By acceptance of this paper, the publisher and/or recipient acknowledges the U.S. Government's right to retain a nonexclusive, royalty-free license in and to any copyright covering this paper, along with the right to reproduce and to authorize others to reproduce all or part of the copyrighted paper. 


\section{WESTINGHOUSE SAVANNAH RIVER COMPANY INTEROFFICE MEMORANDUM}

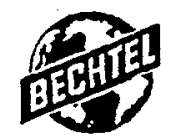

WSRC-RP-99-00846

September 15, 1999

TANKS FOCUS AREA

PRODUCT DELIVERY EXPECTATIONS

IDAHO LOW ACTIVITY WASTE IMMOBILIZATION

E. W. Holtzscheiter

Technology Integration Manager

Immobilization

And

John R. Harbour

Savannah River Technology Center

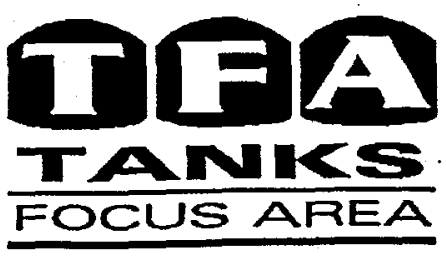




\section{PRODUCT DELIVERY EXPECTATIONS \\ Conditioning and Immobilization of LAW to Meet Waste Acceptance Criteria}

\section{Executive Summary}

The Idaho Site has been used to produce nuclear materials for the U.S. Department of Energy (DOE) and its predecessors. A large inventory of radioactive and mixed waste, largely generated during uranium processing, has resulted in 10 tanks (plus 1 spare) with $\sim 5.3$ million liters of liquid waste and $\sim 4000$ cubic meters of calcined waste stored in six bin sets. The current baseline is to process the stored waste, separate the high activity fraction for vitrification and the low activity fraction for immobilization in grout. The residual liquid waste such as unprocessed Sodium Bearing Waste (SBW) and Newly Generated Liquid Waste (NGLW) is being evaluated for separate disposal on an accelerated schedule.

The current focus of this effort is to address the existing liquid wastes (SBW and NGLW). Both waste streams contain sufficient cesium and possibly strontium to require some separation to achieve "contact" processing of the final waste form into grout. During FY98 and FY99, the Idaho National Engineering and Environmental Laboratory (INEEL) worked with AEA Technology, through the Tanks Focus Area to develop grout formulations consistent with Waste Acceptance Criteria for known available disposal facilities. Facilities suitable for receiving the INEEL grouted waste include Envirocare, Inc. and the Hanford Low-Level Burial Grounds (Trenches 31 and 34). To date, formulations for NGLW and SBW (with and without denitration) have been developed and tested. Further optimization will be required to match formulation to the process constraints and to the Waste Acceptance Criteria (WAC) of the selected disposal facility.

During FY00, the technical team will provide technical and engineering support to an INEEL led project to demonstrate the grouting of one of these low-activity waste streams. The demonstration will be designed to allow demonstration of both streams; the order of processing will support INEEL site priorities.

The key elements of the Idaho Low Activity..Waste Task are:

\section{A. Low-Activity Waste Acceptance Criteria.}

One of the two objectives of this task is to design and hold a technical exchange on low-activity waste acceptance criteria and waste form qualification. The focus of this exchange will be to identify key criteria and processes for qualification of low-activity wastes. The second is to use this information to provide process requirements for the demonstration and to provide a basis for selecting the disposal facility for the initial immobilized waste streams resulting from the demonstation.

B. Prepare the technical basis and support the Idaho project for demonstrating immobilization of SBW and NGLW.

This task umbrellas the entire effort. It incorporates the criteria developed in Item A above and the technology developed in the subsequent items of this task and the integrated flowsheet work relating to low-activity waste. Overall, the TFA technical team including Idaho and AEA Technology will provide support to the disposal site selection, facility descriptions, options cost evaluations, storage and transportation, and permitting requirements. In addition, the flowsheet for the process will be defined and related to the disposal site WAC's. Equipment performance experience will be supported by AEA Technology and will be supported under EM-30 funding. Overall integration of the technology with the demonstration facility will be provided by INEEL with input from the TFA technical team. The start of the radioactive demonstration is planned for early FY02.

C. Evaluation of denitration for the LAW fraction of the INEEL pretreated HLW stream. Denitration processes applicable to Idaho waste were evaluated in previous years work. Thermal denitration was selected as the best option for Idaho. As the process requirements mature and the 
individual unit operations are integrated under this task and the Integrated Flowsheet task, cost effectiveness of denitration can be assessed.

D. Conditioning of the LAW streams.

In order to meet the expected WAC for viable disposal facilities and to support cost effective processing, some pretreatment of the waste stream is expected. From a processing perspective, "contact" rather than remote facility maintenance and operations is generally desirable. From a disposal perspective, selective removal of key isotopes may improve waste loading and provide additional disposal options. These attributes will have to be weighed versus cost of pretreatment. Removal of cesium, strontium, and possibly transuranics (TRU) will be considered. Technologies developed previously by TFA or that are commercially available will be the focus.

E. Evaluation of sorbents or stabilizers for RCRA constituents. Idaho waste is listed RCRA and must be de-listed or disposed of in a RCRA facility. The scope of this task is to identify from literature and experimental work, sorbents and stabilizers that will ensure that the selected RCRA constituents meet regulatory requirements. Oak Ridge has a similar need for stabilization of their tank wastes which are characteristically hazardous. These efforts will be coordinated even though the waste forms are different.

F. Finalize the grout formulation for INEEL SBW and NGLW.

As results from the previous tasks are developed, some tweeking of the formulations may improve cost or processing. This effort is aimed at integrating all of the key data into a final grout formulation for Idaho. AEAT is the lead on this effort.

\section{Discussion of Key Deliverables}

A. Low-Activity Waste Acceptance Technology Exchange: A meeting will be held in the first half of FYO0 to review existing approaches and facilities for disposal of LAW. The meeting will incorporate input from related closure activities, but the focus will be on Idaho requirements. The output of this meeting will provide input to Idaho for selection of a disposal facility for the waste immobilized in the planned FY01-02 demonstration. The key elements of waste form acceptance and performance as they relate to the regulatory process will be discussed. The outcome of the meeting will be documented in a report for use in both immobilization and closure activities.

B. Technical Basis Document and Support to the Idaho Demonstration of Immobilization of SBW and NGLW: A year-end report that provides a status of the technical basis as input to the Idaho Project Management Team working on the LAW grout demonstration will be completed. It will include discussions of the process and equipment, with recommendations.

C. Evaluation of Denitration of the LAW Fraction of the INEEL Pretreated HLW Stream: The results of previous work (both TFA and EM-30) will be incorporated into the flowsheet integration efforts and an initial evaluation of the cost viability of using denitration will be completed.

D. Conditioning of the LAW Stream: The effectiveness of cesium, strontium and/or TRU removal techniques will be documented for use in the determining the extent of pretreatment to be included in the demonstration. Cost versus operational exposure and waste loading will be the key factors.

E. Evaluation of sorbents and stabilizers: The Idaho portion of this task will leverage off of the work being initiated by Oak Ridge. Oak Ridge will perform the initial literature survey and initiate radioactive work relevant to their tank wastes and privatized waste form. The Idaho process and waste form will be different and Idaho will document candidate stabilizers compatible with grouting.

F. Finalize the grout formulation for INEEL SBW and NGLW: Once the disposal site has been selected and the process constraints defined versus the WAC, AEAT will optimize the existing grout formulation for cost and performance. This task may slip into the first part of FY01 depending on progress on the demonstration project. 
WSRC-RP-99-00846

September 15, 1999

Page 4

\section{Keyz Product Requirements}

- Grouting facility must include process steps to immobilize both SBW and NGLW.

- The final waste form must meet the WAC for an available disposal facility.

- Additives must be consistent with the waste form and the WAC for the selected disposal facility.

- The initial demonstration must be achieved prior to FY03.

\section{Task/Product Review Strategy}

A consensus of experts will be developed through the Technical Exchange on waste form acceptance criteria related to low-activity waste for Idaho. John Harbour will review waste form compositions for leveraging from previous TFA work in immobilization and Larry Bustard will be consulted on areas identified in the Immobilization-Closure Interface Meeting for potential overlap.

Technical reports and test plans will be reviewed by at least one expert not working on the specific task and/or a cognisant Technical Advisory Group member.

\section{Roles and Responsibilities}

INEEL and AEA Technology are the principal investigators for the Low-Activity Waste grouting tasks. Idaho will provide overall integration and EM-30 project management for the demonstration. The technical task plans and reports will be reviewed by the Immobilization Technology Integration Manager for both content and overall program integration. SRTC (John Harbour) will organize and summarize the waste acceptance technology exchange meeting with support and input from Alan Herbst, INEEL.

\section{Summary}

Idaho program priorities are highly sensitive to existing HLW operations, particularly the HLW calciner. Therefore, the demonstration will be designed to process both SBW and NGLW, with a sufficiently flexible pretreatment step to address the radiation exposure issues and isotopic requirements for the selected disposal facility. The goal for the task is to initiate the cold demonstration late in FY01; followed by the radioactive demonstration in early FY02. An early selection of the waste disposal facility is critically important to cost and performance, since the process steps and the extent of pretreatment are controlled by the WACs.

\section{References}

1. "Mid-Year Progress Report on Cementation of INEEL Type 2 Waste", Richard F. Simmons, May 1999, AEAT-5516 Issue 1.

2. "Denitration of High Nitrate Salts Using Reductants", H.D. Smith et al, April 1999, Pacific Northwest National Laboratory, PNNL-12144.

3. "Comparison of High Temperature and Organic-Reductant Thermal Denitration of INTEC Low Activity Waste in a Bench Scale Rotary Reactor-JHP-04-98",Ltr. J. Pao to J. H. Valentine, Lockheed Martin Idaho Technologies Company, December 24, 1998.

4. "Cementation Studies on INEEL Sodium Bearing Waste", R. F. Simmons et al, AEA Technology, September 1997, AEAT-2178.

5. "Processing and Product Criteria for the Cementation of INEEL Low Level Wastes", S. J. Palethorpe and R. F. Simmons, AEA Technology, September, 1997, AEAT-2111 - Issue 1.

6. "Cementation Studies on INEEL Sodium Bearing Waste", R. F. Simmons et al, AEA Technology, September 1997, AEAT-2178 Issue 1.

7. "Cementation Studies on INEEL "Acidic" Sodium Bearing Waste Grout", M. A. Johnson et al, AEA Technology, September 1998, AEAT-4165 Issue 1. 
Idaho Low Activity Waste Immobilization and Disposal



